\title{
Correction to: Statistical methods for predicting tuberculosis incidence based on data from Guangxi, China
}

\author{
Yanling Zheng ${ }^{*}$, Liping Zhang, Lei Wang and Ramziya Rifhat
}

Correction to: BMC Infect Dis 20, 300 (2020).

https://doi.org/10.1186/s12879-020-05033-3

Following publication of the original article [1] the authors made an error in the data source description, described below. To this end, the authors sincerely apologize to Guangxi Center for Disease Control and Prevention, China.

- Incorrect description: The data of the TB cases in Guangxi from January 2012 to June 2019 was obtained from the Guangxi center for Disease Control and Prevention, China (please see Data source section.

- Corrected sentence: The data of the TB cases in Guangxi from January 2012 to June 2019 was obtained from the website of Guangxi Health Management Committee (http://wsjkw.gxzf.gov.cn/ zfxxgk_49572/ggws/fdcrbyqgb/t5518731.shtml).

The following sections have also been revised accordingly:

\section{Availability of data and materials.}

The data used in this study are available from the corresponding author on reasonable request. The relevant data is provided as Additional file 1.

Ethics approval and consent to participate.

The research did not involve any direct participation by human subjects. The TB data were extracted from monthly reports maintained on public website (http://wsjkw.gxzf.gov.cn/zfxxgk_49572/ggws/

fdcrbyqgb/t5518731.shtml).

Published online: 25 August 2020

\section{Reference}

1. Zheng $Y$, et al. Statistical methods for predicting tuberculosis incidence based on data from Guangxi, China. BMC Infect Dis. 2020;20:300. https://doi. org/10.1186/s12879-020-05033-3.

The original article can be found online at https://doi.org/10.1186/s12879020-05033-3.

* Correspondence: zhengyl_math@sina.cn

College of Medical Engineering and Technology, Xinjiang Medical University, Urumqi 830011, People's Republic of China

(c) The Author(s). 2020 Open Access This article is licensed under a Creative Commons Attribution 4.0 International License, which permits use, sharing, adaptation, distribution and reproduction in any medium or format, as long as you give appropriate credit to the original author(s) and the source, provide a link to the Creative Commons licence, and indicate if changes were made. The images or other third party material in this article are included in the article's Creative Commons licence, unless indicated otherwise in a credit line to the material. If material is not included in the article's Creative Commons licence and your intended use is not permitted by statutory regulation or exceeds the permitted use, you will need to obtain permission directly from the copyright holder. To view a copy of this licence, visit http://creativecommons.org/licenses/by/4.0/ The Creative Commons Public Domain Dedication waiver (http://creativecommons.org/publicdomain/zero/1.0/) applies to the data made available in this article, unless otherwise stated in a credit line to the data. 